PLASMA LEVEL OF SOLUBLE UROKINASE-TYPE PLASMINOGEN ACTIVATOR RECEPTOR PREDICTS THE SEVERITY OF ACUTE ALCOHOL PANCREATITIS

Anssi Nikkola

Syventävien opintojen kirjallinen työ

Tampereen yliopisto

Lääketieteen ja biotieteiden tiedekunta Maaliskuu 2017 
Tampereen yliopisto

Lääketieteen ja biotieteiden tiedekunta

Tampereen Haimaryhmä

\section{NIKKOLA ANSSI: PLASMA LEVEL OF SOLUBLE UROKINASE-TYPE PLASMINOGEN ACTIVATOR RECEPTOR PREDICTS THE SEVERITY OF ACUTE ALCOHOL PANCREATITIS}

Kirjallinen työ, 8s.

Ohjaaja: dosentti Johanna Laukkarinen

Maaliskuu 2017

Tutkimuksen tarkoituksena oli selvittää plasman liukoisen urokinaasityyppisen plasminogeenia aktivoivan reseptorin (suPAR) aktivoitumista ja ennusteellista arvoa akuutissa alkoholihaimatulehduksessa.

UPAR (urokinase-type plasminogen activator receptor) on solukalvoproteiini, jota ilmenee monissa elimistön soluissa, esimerkiksi useissa puolustusjärjestelmän soluissa kuten monosyyteissä, Tlymfosyyteissä, makrofageissa, sekä tietyissä syöpäsoluissa. SuPAR on tämän proteiinin liukoinen muoto. SuPAR-pitoisuuden on todettu nousevan puolustusjärjestelmän aktivaation seurauksena ja kohonnut suPAR-pitoisuus on merkki inflammaatiosta. Liukoisen urokinaasityyppisen plasminogeenia aktivoivan reseptorin (suPAR) ennusteellista arvoa on tutkittu sepsiksessä ja SIRS:ssä (systemic inflammatory response syndrome), kroonisissa ja akuuteissa maksasairauksissa sekä useissa syövissä, kuten haiman adenokarsinoomassa. Akuutissa haimatulehduksessa suPAR:n ennusteellista arvoa ei ole aikaisemmin tutkittu.

Prospektiivisesti kerätty aineisto käsitti 104 ensimmäisen alkoholiperäisen haimatulehduksen sairastanutta potilasta. Plasman suPAR-pitoisuudet määritettiin pian sairaalaan tulon jälkeen, ja uudelleen kotiuttamisen jälkeen. Haimatulehduksen vaikeusaste määriteltiin kansainvälisten kriteerien mukaisesti laboratoriokokeita, potilaan kliinistä kuvaa sekä kuvantamislöydöksiä apuna käyttäen.

P-suPAR pitoisuudet olivat merkitsevästi korkeampia potilailla sairaalahoidon aikana verrattuna kotiuttamisen jälkeen mitattuihin arvoihin. Vaikeamman taudinkuvan haimatulehduksissa P-suPAR oli huomattavasti korkeampi verrattuna lieviin tapauksiin. P-suPAR osoittautui tässä potilasaineistossa paremmaksi alkuvaiheen ennusteelliseksi merkkiaineeksi kuin tällä hetkellä kliinisessä käytössä olevat työkalut (C-reaktiivinen proteiini, hematokriitti tai kreatiniini).

Tutkimustulokset osoittavat, että plasman suPAR-arvot ovat koholla akuutissa alkoholihaimatulehduksessa ja korreloivat hyvin taudin vaikeusasteen kanssa. Johtopäätöksenä todetaan, että P-suPAR on uusi potentiaalinen työkalu akuutin haimatulehduksen vaikeusasteen määrittämiseksi taudin alkuvaiheessa. 


\title{
Plasma Level of Soluble Urokinase-type Plasminogen Activator Receptor Predicts the Severity of Acute Alcohol Pancreatitis
}

\author{
Anssi Nikkola, BM, *广 Janne Aittoniemi, MD, PhD,, Reetta Huttunen, MD, PhD, $\S$ Linnea Rajala, BM, $\dagger$ \\ Isto Nordback, $M D, P h D,{ }^{*}$ Juhani Sand, $M D, P h D,{ }^{*}$ and Johanna Laukkarinen, $M D, P h D *$
}

Objectives: Systemic levels of soluble urokinase-type plasminogen activator receptor (suPAR) are increased in various inflammatory and infectious diseases. We investigated the activation and prognostic value of plasma suPAR (P-suPAR) in patients experiencing their first acute alcohol pancreatitis (AAP).

Methods: From prospectively collected data, we measured P-suPAR concentrations in 104 patients with AAP during hospitalization and again after discharge.

Results: According to the revised Atlanta classification, pancreatitis was moderately severe in $29(28 \%)$ and severe in $6(6 \%)$ patients and these severities were combined for further analysis (non-mild AAP, $n=35 ; 34 \%$ ). Median P-suPAR levels were significantly higher in patients with AAP during hospitalization than after discharge $(4.8 \mathrm{vs} 3.1 \mathrm{ng} / \mathrm{mL} ; P<0.001)$ and in non-mild compared to mild AAP ( $6.2 \mathrm{vs} 4.2 \mathrm{ng} / \mathrm{mL} ; P<0.001$ ). When the analysis was made 1 to 4 days after admission $(n=68)$, the area under the curve was 0.81 ( $95 \%$ confidence interval, $0.70-0.92$ ). P-suPAR was found to be a better prognostic marker in AAP than C-reactive protein, hematocrit, or creatinine.

Conclusions: P-suPAR concentrations are elevated in AAP and correlate with the severity of the disease. These results suggest that P-suPAR may have potential to serve as a novel prognostic marker for AAP severity on admission.

Key Words: acute alcohol pancreatitis, prognosis, suPAR, soluble urokinase-type plasminogen activator receptor

(Pancreas 2017;46: 77-82)

A cute pancreatitis (AP) is an inflammatory disease with an increasing incidence and wide spectrum of severity and is one of the most common gastrointestinal diseases requiring hospitalization. ${ }^{1}$ Gallstones and alcohol are the main etiologies with biliary pancreatitis predominating in most countries. ${ }^{2,3}$ In Finland, alcohol is the leading cause of morbidity accounting for approximately $70 \%$ of cases. ${ }^{4,5}$

In AP, premature activation of trypsin causes pancreatic autodigestion and results in a local inflammatory process. The release of cytokines and other inflammatory mediators is characteristic of this process, which results in the recruitment of various immune cells. ${ }^{6}$ Urokinase-type plasminogen activator receptor (uPAR) is a membrane protein expressed in cells such as monocytes, neutrophils,

From the *Department of Gastroenterology and Alimentary Tract Surgery, Tampere University Hospital; †University of Tampere, School of Medicine; \$Fimlab Laboratories; and §Department of Internal Medicine, Tampere University Hospital, Tampere, Finland.

Received for publication September 12, 2015; accepted July 13, 2016.

Address correspondence to: Johanna Laukkarinen, MD, PhD, Department of Gastroenterology and Alimentary Tract Surgery, Tampere University

Hospital, Teiskontie 35, FIN-33521 Tampere, Finland

(e-mail: johanna.laukkarinen@fimnet.fi).

This study was supported by the Competitive State Research Funding of the Expert Responsibility Area of Tampere University Hospital (X50060), and by the Sigrid Jusélius Foundation, Finland.

The authors declare no conflict of interest.

Copyright (C) 2016 Wolters Kluwer Health, Inc. All rights reserved.

DOI: $10.1097 /$ MPA.0000000000000730 activated T-lymphocytes, macrophages, endothelial cells, and cancer cells. ${ }^{7-9}$ Systemic levels of its soluble form (suPAR) are associated with activation of the immune system and inflammatory processes. ${ }^{9,10}$ Systemic levels of suPAR are documented to have prognostic value in sepsis ${ }^{11}$ and systemic inflammatory response syndrome ${ }^{12}$ as well as in various cancers, including pancreatic ductal adenocarcinoma, ${ }^{13}$ gastric cancer, ${ }^{14}$ and colorectal cancer. ${ }^{15}$

Acute pancreatitis is usually a self-limiting disease that resolves within days, but around $20 \%$ of patients develop a more severe disease including local complications and/or organ failure defined in the revised Atlanta classification. ${ }^{16,17}$ Pancreatic necrosis as well as presence of organ failure in AP is associated with significant mortality and, therefore, early risk stratification is of clinical importance. ${ }^{18-21}$

At least 9 scoring systems, ${ }^{22}$ aiming to determine the severity of AP on admission, have been described, such as Acute Physiology and Chronic Health Examination (APACHE II), ${ }^{23}$ the Ranson criteria, ${ }^{24}$ and Modified Glasgow Score. ${ }^{25}$ In addition to elaborative scoring systems, attention has also focused on finding an individual laboratory marker to assess the severity of AP, such as hematocrit ${ }^{26} \mathrm{C}$-reactive protein (CRP), ${ }^{27}$ creatinine, ${ }^{28}$ procalcitonin, ${ }^{29}$ and serum urea nitrogen. ${ }^{30}$ Despite numerous candidates proposed for predicting the severity of $\mathrm{AP}$, no consensus on criterion has been reached and new approaches are needed..$^{22}$

Our aim was to study the activation and prognostic value of plasma suPAR (P-suPAR) in patients experiencing their first acute alcohol pancreatitis (AAP).

\section{MATERIALS AND METHODS}

The study population consisted of 120 patients with first AAP. The patients were admitted to Tampere University Hospital between January 2001 and March 2005. In this study, patient recruitment, clinical data collection, and sample collection were conducted prospectively. The patient data used in this study have been studied previously and published in a randomized controlled trial from the same group. ${ }^{31}$ From the 120 patients with AAP, blood samples taken during hospitalization were available from 104 patients.

Diagnosis of AAP was based on typical clinical features (epigastric pain, nausea, vomiting) and elevated pancreatic enzymes (amylase at least 3 times over the normal upper limit). Ultrasonography and/or computed tomography were performed to confirm the diagnosis if necessary. Alcohol was determined as the probable etiology by history of heavy drinking, laboratory markers such as carbohydrate-deficient transferrin, mean corpuscular volume, and glutamyltransferase; questionnaires such as Alcohol Use Disorders Identification Test (AUDIT) and Short Alcohol Dependence Data (SADD); and exclusion of other possible etiologies (biliary, autoimmune, trauma, medication, hypertriglyceridemia, hypercalcemia, and hereditary).

Acute pancreatitis was classified according to the revised Atlanta classification into mild (pancreatic inflammation only), moderately severe (transient organ failure that resolves within 48 hours and/or local or systemic complications), and severe (persistent organ failure, $>48$ hours). ${ }^{17}$ For the statistical analysis, 
TABLE 1. Demographic and Clinical Characteristics of Patients With Mild and Non-mild AAP

\begin{tabular}{|c|c|c|c|}
\hline Characteristics & Mild $(n=69)$ & Non-mild $(n=35)$ & $\boldsymbol{P}$ \\
\hline Sex (female/male) & $12 / 57$ & $7 / 28$ & 0.74 \\
\hline Age, $\mathrm{y}^{*}$ & $47(18-73)$ & $47(25-70)$ & 0.58 \\
\hline Length of hospital stay, $\mathrm{d}^{*}$ & $6(2-28)$ & $10(5-41)$ & $<0.001$ \\
\hline Hospital mortality & 0 & 0 & NA \\
\hline AUDIT* & $20(5-38)$ & $23(7-38)$ & 0.047 \\
\hline $\mathrm{SADD}^{*}$ & $10(0-36)$ & $15(2-33)^{\dagger}$ & 0.013 \\
\hline Alcohol consumption $(\mathrm{g} / 2 \mathrm{mo})^{*}$ & $2688(288-13,440)$ & $3744(504-16,128)^{\dagger}$ & 0.003 \\
\hline Smoking & & $\dagger$ & 0.93 \\
\hline Yes $(\%)$ & $42(61)$ & $21(63)$ & \\
\hline No $(\%)$ & $27(39)$ & $13(37)$ & \\
\hline
\end{tabular}

*Median (range).

${ }^{\dagger} \mathrm{n}=34$, data unavailable from 1 patient.

moderately severe and severe AAP were combined and are here referred to as non-mild AAP

Samples for P-suPAR determination were taken during hospitalization (median 4 days after admission; from 68 patients on days 1-4) from 104 patients with their first AAP and stored at $-70^{\circ} \mathrm{C}$. Control samples were obtained from $78(75 \%)$ patients 6 to 24 months after discharge from the hospital. From the control samples, 1 patient with acute appendicitis at the time of the follow-up visit was excluded. Thus, the final control group consisted of 77 patients.

Plasma suPAR concentrations were measured using a commercial enzyme-linked immunosorbent assay from Virogates A/S (Birkerød, Denmark) according to manufacturer's instructions.

\section{Statistical Analysis}

Statistical analysis was carried out using IBM SPSS Statistics for Windows (Version 21.0, Armonk, NY). P values under 0.05 were considered statistically significant. Because of the skewness of the data, Kruskal-Wallis (comparison between more than 2 groups) or Mann-Whitney $U$ (comparison between 2 groups) nonparametric tests were used to test for statistical significance. The $x^{2}$ test was used to test for statistical significance between 2 categorical variables, and Wilcoxon signed rank test between related samples, respectively. Value of P-suPAR as an independent marker was evaluated using binomial logistic regression model adjusted for potential confounders. Receiver operating characteristic (ROC) curves as well as sensitivity, specificity, and predictive values were used to determine the prognostic value of suPAR and commonly used laboratory markers (CRP, hematocrit, and creatinine). The optimal cutoff value for P-suPAR in predicting the severity of AAP was determined using the Youden index (highest sum of sensitivity and specificity; sensitivity + specificity -1 ). The Kaplan-Meier curve was used to determine the cumulative incidence of complications in AAP and the differences between groups were compared using the log-rank test. The results are presented as medians, ranges, and interquartile ranges (IQRs)

\section{RESULTS}

Acute alcohol pancreatitis was considered mild in $69(66 \%)$, moderately severe in $29(28 \%)$, and severe in $6(6 \%)$ patients. For further analysis, moderately severe and severe AAP were combined, and referred to as non-mild AAP $(\mathrm{n}=34 ; 35 \%)$. The demographic and clinical characteristics of patients with mild and non-mild AAP are shown in Table 1. Amount of alcohol consumed before an episode of pancreatitis and the length of hospital stay were associated with the severity of AAP. During the first 4 days after admission, female sex was associated with significantly higher P-suPAR values and smoking suggested a trend for significance as seen in Table 2 . There were no significant differences between P-suPAR values on days 1 to $2(n=26)$ and values on days 3 to $4(\mathrm{n}=42)$ in mild (median, 4.2; IQR, 3.0-5.0 vs 4.0; $2.9-4.7 \mathrm{ng} / \mathrm{mL}, P=0.43)$ or non-mild AAP $(6.2 ; 5.5-9.4$ vs 5.7 ; $4.7-6.5 \mathrm{ng} / \mathrm{mL}, P=0.46)$.

Median P-suPAR concentrations were significantly higher in non-mild AAP $(6.2 \mathrm{ng} / \mathrm{mL}, 5.0-7.9)$ than in mild AAP $(4.2 \mathrm{ng} / \mathrm{mL}$, 3.1-5.6; $P<0.001)$. The significance also remained in a binomial regression analysis adjusted for potential confounders (age, sex, alcohol consumption, AUDIT, SADD, smoking status, and admission laboratory markers; CRP, creatinine, hematocrit) with an OR of $1.2(95 \%$ confidence interval [CI], 1.0-1.5). suPAR was the only variable to reach statistical significance in the multivariate analysis.

The prognostic value of P-suPAR in assessing AAP severity was quantified by determining the area under the curve (AUC) from the ROC curve. When the analysis was made 1 to 4 days after admission ( 68 patients; mild $n=54 ; 79 \%$, non-mild $n=14$;

TABLE 2. P-suPAR (1-4 Days After Admission, $n=68$ ) in Correlation With Sex, Smoking Status, and Severity of AAP

\begin{tabular}{lcc}
\hline Variable & P-suPAR $(\mathbf{n g} / \mathbf{m L})^{*}$ & $\boldsymbol{P}$ \\
\hline Sex & & \\
$\quad$ Male & $4.0(3.1-5.1)$ & 0.019 \\
Female & $5.5(4.2-6.3)$ & \\
Smoking $^{\dagger}$ & & \\
$\quad$ Yes & $4.7(3.5-6.1)$ & 0.053 \\
$\quad$ No & $3.6(2.9-4.8)$ & \\
Severity & & \\
$\quad$ Mild & $4.1(3.0-4.8)$ & \\
Non-mild & $6.0(4.9-6.5)$ & \\
\hline
\end{tabular}

*All numerical data are median (IQR).

$\mathrm{n}=67$, data unavailable from 1 patient. 

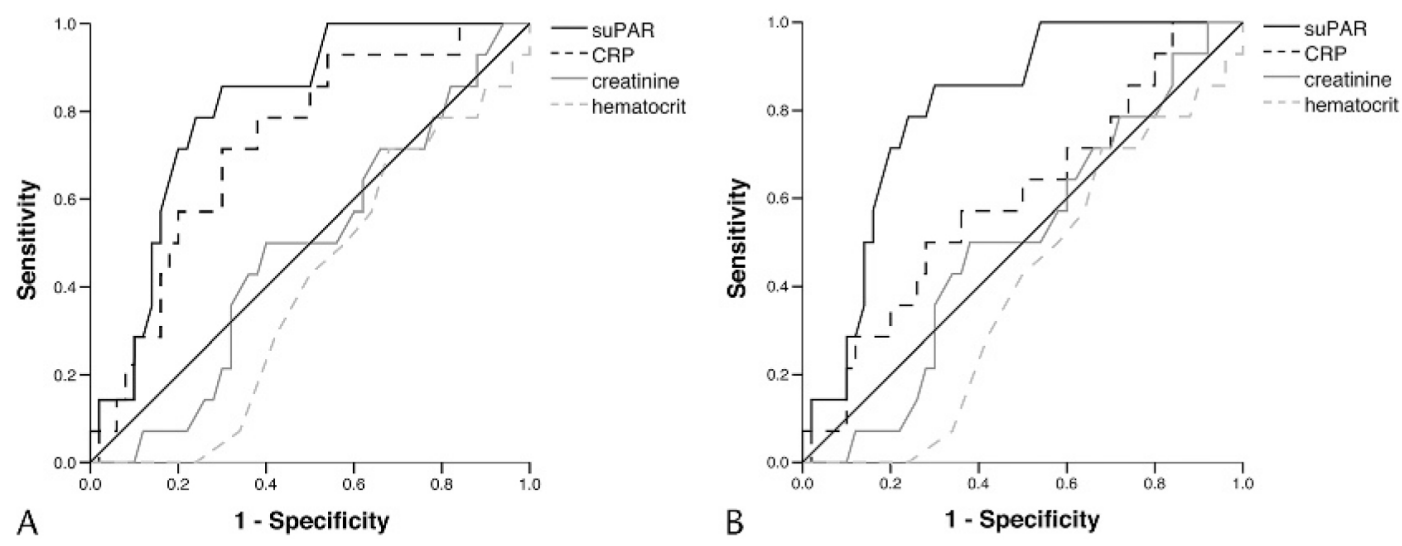

FIGURE 1. ROC curves of suPAR, CRP, creatinine, and hematocrit. Creatinine was unavailable from 4 patients from whom hematocrit was unavailable from 2 and CRP from 1 of the same patients $(n=64)$. A, suPAR, maximum CRP, and maximum creatinine are detected on days 1 to 4 and hematocrit on admission (0). B, suPAR detected on days 1 to 4 and CRP, creatinine, and hematocrit on admission.

$21 \%)$, AUC was 0.81 (95\% CI, 0.70-0.92). The AUC values for commonly used predictive laboratory markers were lower than those for P-suPAR (Fig. 1).

An optimal cutoff level for non-mild AAP on admission was estimated from the ROC curve using the Youden index. At a cutoff level of $5.0 \mathrm{ng} / \mathrm{mL}$, sensitivity and specificity to predict a nonmild AAP were $79 \%$ and $78 \%$, respectively, as seen in Table 3 . High suPAR values $(\geq 5.0 \mathrm{ng} / \mathrm{mL})$ were also associated with a significantly higher rate of total complications in AAP (Fig. 2). To identify patients with mild disease a cutoff level with $100 \%$ sensitivity was determined from the ROC curve. At a cutoff level of $3.7 \mathrm{ng} / \mathrm{mL}, 24$ of 68 patients received values below cutoff with sensitivity and negative predictive value of $100 \%$ (Table 3 ). The suPAR values in non-mild and mild disease analyzed early during an episode (days 1-4) of AAP as well as in recovery are illustrated in Figure 3.

In a binomial regression analysis adjusted for potential confounders (age, sex, alcohol consumption, AUDIT, SADD, smoking status, and admission laboratory markers; CRP, creatinine, hematocrit), only high P-suPAR ( $\geq 5.0 \mathrm{ng} / \mathrm{mL}$ ) on days 1 to 4 remained as an independent marker for severity in AAP (OR, 21.1; 95\% CI, 2.8-160.7).

We analyzed P-suPAR values from 77/104 patients 6 to 24 months after the initial episode of AAP and found that median P-suPAR decreased to low levels after recovery $(3.1 \mathrm{ng} / \mathrm{mL}$, 2.7-3.8) compared to those measured during an episode of AAP in the same patients $(4.7 \mathrm{ng} / \mathrm{mL}, 3.6-6.3 ; P<0.001)$.

\section{DISCUSSION}

Several scoring systems and single laboratory markers have been proposed to assess the severity of AP on admission, but they remain far from optimal. No studies have so far investigated the role of suPAR in AP. We investigated whether P-suPAR correlates with disease severity and whether it has any value as a prognostic biomarker in AAP. We found that P-suPAR is elevated in AAP and is significantly higher in patients with non-mild disease compared to those with mild AAP. Furthermore, we were able to demonstrate that P-suPAR has prognostic value as an independent marker of severity in terms of distinguishing between mild and non-mild AAP on admission. In addition to predicting non-mild AAP, suPAR could be viewed as a prognostic tool for detecting mild AAP. As a usually self-limiting disease, mild pancreatitis requires mostly fluid resuscitation and pain relief and could therefore be triaged to a different treatment setting than moderately severe or severe disease. Combined with the clinical features, suPAR could help in stratifying these patients with mild disease.

In an earlier study, urinary suPAR levels were found to be elevated in chronic pancreatitis (CP) compared to healthy controls but the prognostic value in $\mathrm{CP}$ was not investigated further. ${ }^{13}$ As a biomarker, suPAR has been found to have limited diagnostic power as suPAR is a nonspecific marker of inflammation. ${ }^{32,33}$ suPAR has been investigated and found to have potential prognostic value in sepsis, ${ }^{11}$ systemic inflammatory response syndrome, ${ }^{12}$ liver diseases including alcoholic liver disease, ${ }^{34}$ and cancers including ductal adenocarcinoma. ${ }^{13}$ Tuomi et $\mathrm{al}^{34}$ reported that heavy alcohol consumption without diagnosed alcoholic liver disease was associated with higher P-suPAR values than in healthy controls. After an episode of AAP, some of the patients in our study may have developed morphological changes applicable to $\mathrm{CP}$ and some may have continued heavy alcohol consumption. These factors are the probable explanations for the slightly higher P-suPAR values reported in our study population after recovery from AAP compared to values reported in healthy controls in other studies. ${ }^{14,32,34}$ During the first 4 days after admission, female sex and smoking were associated with higher suPAR values in our study. Smoking has previously been reported to increase suPAR values but to the best of our knowledge, no link between

TABLE 3. Prognostic Value of P-suPAR With 2 Different Cutoff Levels

\begin{tabular}{lcccc}
\hline & Sensitivity & Specificity & Positive Predictive Value & Negative Predictive Value \\
\hline Cutoff, $\mathrm{ng} / \mathrm{mL}$ & & & & \\
$\geq 5.0$ & $79 \%$ & $78 \%$ & $48 \%$ & $93 \%$ \\
$\geq 3.7$ & $100 \%$ & $44 \%$ & $32 \%$ & $100 \%$ \\
\hline
\end{tabular}


female sex and higher P-suPAR has been reported. ${ }^{35}$ In our study, $81 \%$ of the women were smokers compared to $58 \%$ in men. Also, the women had more non-mild disease than the men $(5 / 16 ; 31 \%$ in women vs $9 / 52 ; 17 \%$ in men) but this difference was not statistically significant $(P=0.23)$. Furthermore, smoking status and sex were statistically insignificant factors in the multivariate analysis in predicting the severity of the disease.

The major limitation of the present study was that samples obtained on days 1 to 4 after admission were used to determine the prognostic value of suPAR in AAP. However, earlier studies have shown that P-suPAR remains stably elevated during the first week in general intensive care unit population and bacteremic patients. ${ }^{1,32}$ To the best of our knowledge, no studies have been conducted specifically on the half-life of suPAR, but in vitro suPAR proved to be very stable and less susceptible to freezing and thawing than other inflammatory markers. ${ }^{36}$ In addition, P-suPAR levels did not differ significantly between days 1 to 2 and days 3 to 4 in our study. Severe AP, as classified according to the revised Atlanta classification, ${ }^{17}$ is associated with a mortality of $30 \%$ or even higher. ${ }^{21,37}$ However, in our study, all patients survived the episode of AAP. Thus, it may be that the patients with the most severe disease were not involved in our study, and the suPAR levels of those patients might have been even higher than those of the patients analyzed within the present study. In addition, as the number of severe AAP cases in our study was low $(n=6)$, analysis of severe and moderately severe AAP could not be conducted separately.

With a cutoff level of $3.7 \mathrm{ng} / \mathrm{mL}$, P-suPAR was below cutoff in 24 patients with mild AAP with an accuracy of $100 \%$. This means that, in our study, one third of the patients with AAP could potentially be treated in nonspecialized centers or on an outpatient basis. Detecting the patients with a certain mild disease on admission would be beneficial when planning the level of treatment. As AP is one of the most common gastrointestinal diseases requiring hospitalization, identifying these patients could lead to substantially more cost-effective care in pancreatitis. However, this finding should be assessed in a large prospective cohort to

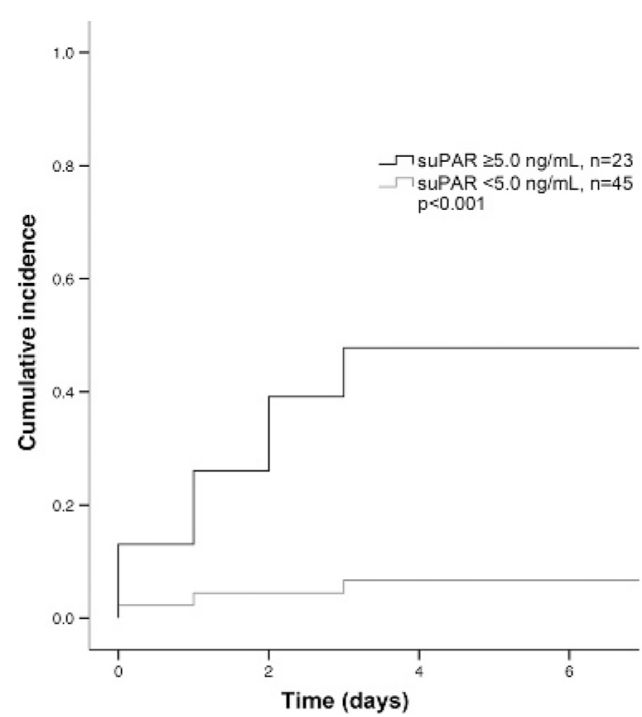

FIGURE 2. Kaplan-Meier curve showing the cumulative incidence of complications classified in the revised Atlanta classification in patients with high $(\geq 5.0 \mathrm{ng} / \mathrm{mL})$ and low $(<5.0 \mathrm{ng} / \mathrm{mL})$ suPAR values. The differences between the groups were calculated using the log-rank test.

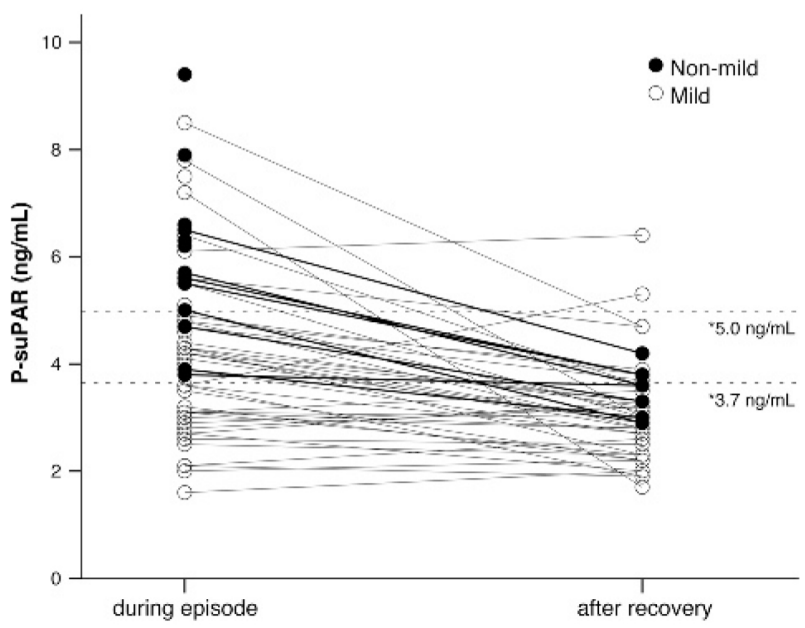

FIGURE 3. Line chart presenting P-suPAR values in mild (open dots) and non-mild (filled dots) AAP analyzed early during an episode (days 1-4) of pancreatitis and after recovery from the disease. *5.0 and $3.7 \mathrm{ng} / \mathrm{mL}$ cutoff levels determined from the ROC curve.

eliminate the possibility of chance and with regard to the effect of the interventions.

Several scoring systems and single laboratory markers have been proposed to assess the severity of AP, APACHE II being probably the most validated scoring system with good sensitivity and specificity and used as a reference system in many studies. APACHE II was originally developed for general intensive care unit population and requires multiple parameters, of which some are not relevant in AP, and therefore it might be considered time consuming and cumbersome. Some of the scoring systems, for example, the Ranson criteria, require 48 hours to complete, while the highest incidence of organ failure occurs during the first 24 hours. ${ }^{38}$ In sepsis, suPAR was found to improve prognostic accuracy and complement a scoring system when combined with APACHE II. ${ }^{39}$ Compared to the prognostic accuracy of other prognostic markers and scoring systems studied by Mounzer et al, ${ }^{22}$ suPAR could offer competitive accuracy according to our study. We routinely check for other possible etiologies for AP in our clinic and if necessary exclude these by history, liver chemistry, serum calcium and lipid measurements, and ultrasonography/computed tomography. As suPAR is a nonspecific marker for inflammation, there is nevertheless a possibility of an underlying disease that may elevate suPAR, and therefore suPAR should probably be viewed as a general marker of inflammation as is CRP.

Earlier studies have reported varying results regarding the prognostic values of creatinine and hematocrit in AP, ranging from minor to good prognostic significance..$^{26,28,40,41}$ In our study, creatinine and hematocrit were of little prognostic value in discriminating between mild and non-mild AAP, possibly due to the small number of severe pancreatitis cases. C-reactive protein as a single marker of severity in AP has been studied and is probably the most widely used individual laboratory marker in clinical practice. ${ }^{42} \mathrm{C}$-reactive protein values rise gradually in the course of AP and the best prognostic value in AP is achieved 24 to 48 hours after admission, due to which the potential for early stratification may be lost. ${ }^{27}$ This was also established in our study as the AUC of CRP was rather limited on admission. In our study, the prognostic value of P-suPAR was higher than that of CRP on admission or maximum CRP at 1 to 4 days after admission. Although new strategies in triaging patients with AP are needed, we have demonstrated 
that suPAR is a viable candidate as a single biomarker for assessing the severity of AAP.

\section{CONCLUSIONS}

In this study, we found that P-suPAR values are elevated in AAP and correlate with the severity of the disease. In addition, we were able to demonstrate that P-suPAR has a value as an independent marker of severity in distinguishing between mild and non-mild AAP. These results suggest that P-suPAR may have potential to serve as a novel prognostic marker and a stratification tool for AAP severity on admission to hospital. Potentially, combined with the clinical features, P-suPAR could be used in clinics to exclude moderately severe or severe forms of AAP on admission, thus detecting the mild forms of the disease suitable for treatment in nonspecialized centers or on an outpatient basis.

\section{ACKNOWLEDGMENTS}

The authors thank the staff of Fimlab Laboratories, Tampere, Finland, for their competent technical assistance, and for the use of laboratory facilities.

\section{REFERENCES}

1. Peery AF, Dellon ES, Lund J, et al. Burden of gastrointestinal disease in the United States: 2012 update. Gastroenterology. 2012;143: 1179-1187.

2. Gullo L, Migliori M, Oláh A, et al. Acute pancreatitis in five European countries: etiology and mortality. Pancreas. 2002;24:223-227.

3. Lowenfels AB, Maisonneuve P, Sullivan T. The changing character of acute pancreatitis: epidemiology, etiology, and prognosis. Curr Gastroenterol Rep. 2009;11:97-103.

4. Jaakkola M, Nordback I. Pancreatitis in Finland between 1970 and 1989. Gut. 1993;34:1255-1260.

5. Sand J, Välikoski A, Nordback I. Alcohol consumption in the country and hospitalizations for acute alcohol pancreatitis and liver cirrhosis during a 20-year period. Alcohol Alcohol. 2009;44:321-325.

6. Sakorafas GH, Tsiotou AG. Etiology and pathogenesis of acute pancreatitis: current concepts. J Clin Gastroenterol. 2000;30:343-356.

7. Estreicher A, Mühlhauser J, Carpentier JL, et al. The receptor for urokinase type plasminogen activator polarizes expression of the protease to the leading edge of migrating monocytes and promotes degradation of enzyme inhibitor complexes. J Cell Biol. 1990;111:783-792.

8. Blasi F, Carmeliet P. uPAR: a versatile signalling orchestrator. Nat Rev Mol Cell Biol. 2002;3:932-943.

9. Thunø M, Macho B, Eugen-Olsen J. suPAR: the molecular crystal ball. Dis Markers. 2009;27:157-172

10. Ossowski L, Aguirre-Ghiso JA. Urokinase receptor and integrin partnership: coordination of signaling for cell adhesion, migration and growth. Curr Opin Cell Biol. 2000;12:613-620.

11. Huttunen R, Syrjänen J, Vuento R, et al. Plasma level of soluble urokinase-type plasminogen activator receptor as a predictor of disease severity and case fatality in patients with bacteraemia: a prospective cohort study. J Intern Med. 2011;270:32-40.

12. Raggam RB, Wagner J, Prüller F, et al. Soluble urokinase plasminogen activator receptor predicts mortality in patients with systemic inflammatory response syndrome. J Intern Med. 2014;276:651-658.

13. Sorio C, Mafficini A, Furlan F, et al. Elevated urinary levels of urokinase-type plasminogen activator receptor (UPAR) in pancreatic ductal adenocarcinoma identify a clinically high-risk group. BMC Cancer. 2011;11:448 456 .

14. Fidan E, Mentese A, Ozdemir F, et al. Diagnostic and prognostic significance of CA IX and suPAR in gastric cancer. Med Oncol. 2013;30: $540-544$.
15. Stephens RW, Nielsen HJ, Christensen IJ, et al. Plasma urokinase receptor levels in patients with colorectal cancer: relationship to prognosis. J Natl Cancer Inst. 1999;91:869-874.

16. Banks PA, Freeman ML; Practice Parameters Committee of the American College of Gastroenterology. Practice guidelines in acute pancreatitis. Am J Gastroenterol. 2006;101:2379-2400.

17. Banks PA, Bollen TL, Dervenis C, et al. Classification of acute pancreatitis - 2012: revision of the Atlanta classification and definitions by international consensus. Gut. 2013;62:102-111.

18. Buter A, Imrie CW, Carter CR, et al. Dynamic nature of early organ dysfunction determines outcome in acute pancreatitis. Br J Surg. 2002;89: 298-302.

19. Tenner S. Initial management of acute pancreatitis: critical issues during the first 72 hours. Am J Gastroenterol. 2004;99:2489-2494.

20. Rau B, Bothe A, Beger HG. Surgical treatment of necrotizing pancreatitis by necrosectomy and closed lavage: changing patient characteristics and outcome in a 19-year, single-center series. Surgery. 2005;138:28-39.

21. Petrov MS, Shanbhag S, Chakraborty M, et al. Organ failure and infection of pancreatic necrosis as determinants of mortality in patients with acute pancreatitis. Gastroenterology. 2010;139:813-820.

22. Mounzer R, Langmead CJ, Wu BU, et al. Comparison of existing clinical scoring systems to predict persistent organ failure in patients with acute pancreatitis. Gastroenterology. 2012;142:1476-1482.

23. Larvin M, McMahon MJ. APACHE-II score for assessment and monitoring of acute pancreatitis. Lancet. 1989;2:201-205.

24. Ranson JH, Rifkind KM, Roses DF, et al. Objective early identification of severe acute pancreatitis. Am J Gastroenterol. 1974;61:443-451.

25. Blamey SL, Imrie CW, O'Neill J, et al. Prognostic factors in acute pancreatitis. Gut. 1984;25:1340-1346.

26. Brown A, Orav $\mathbf{J}$, Banks PA. Hemoconcentration is an early marker for organ failure and necrotizing pancreatitis. Pancreas. 2000;20:367-372.

27. Cardoso FS, Ricardo LB, Oliveira AM, et al. C-reactive protein prognostic accuracy in acute pancreatitis: timing of measurement and cutoff points. Eur J Gastroenterol Hepatol. 2013;25:784-789.

28. Muddana V, Whitcomb DC, Khalid A, et al. Elevated serum creatinine as a marker of pancreatic necrosis in acute pancreatitis. Am J Gastroenterol. 2009;104:164-170.

29. Rau B, Steinbach G, Baumgart K, et al. The clinical value of procalcitonin in the prediction of infected necrosis in acute pancreatitis. Intensive Care Med. 2000;26:S159-S164.

30. Wu BU, Bakker OJ, Papachristou GI, et al. Blood urea nitrogen in the early assessment of acute pancreatitis: an international validation study. Arch Intern Med. 2011;171:669-676.

31. Nordback I, Pelli H, Lappalainen-Lehto R, et al. The recurrence of acute alcohol-associated pancreatitis can be reduced: a randomized controlled trial. Gastroenterology. 2009;136:848-855.

32. Koch A, Voigt $\mathrm{S}$, Kruschinski $\mathrm{C}$, et al. Circulating soluble urokinase plasminogen activator receptor is stably elevated during the first week of treatment in the intensive care unit and predicts mortality in critically ill patients. Crit Care. 2011;15:R63.

33. Kofoed K, Andersen O, Kronborg G, et al. Use of plasma C-reactive protein, procalcitonin, neutrophils, macrophage migration inhibitory factor, soluble urokinase-type plasminogen activator receptor, and soluble triggering receptor expressed on myeloid cells-1 in combination to diagnose infections: a prospective study. Crit Care. 2007;11:R38.

34. Tuomi H, Kultti J, Danielsson J, et al. Serum soluble urokinase plasminogen activator receptor in alcoholics: relation to liver disease severity, fibrogenesis, and alcohol use. J Gastroenterol Hepatol. 2014;29: 1991-1995

35. Botha S, Fourie CM, Schutte R, et al. Associations of suPAR with lifestyle and cardiometabolic risk factors. Eur J Clin Invest. 2014;44:619-626. 
36. Kofoed K, Schneider UV, Scheel T, et al. Development and validation of a multiplex add-on assay for sepsis biomarkers using xMAP technology. Clin Chem. 2006;52:1284-1293.

37. Johnson CD, Abu-Hilal M. Persistent organ failure during the first week as a marker of fatal outcome in acute pancreatitis. Gut. 2004;53:1340-1344.

38. Wu BU, Conwell DL. Update in acute pancreatitis. Curr Gastroenterol Rep. 2010;12:83-90.

39. Giamarellos-Bourboulis EJ, Norrby-Teglund A, Mylona V, et al. Risk assessment in sepsis: a new prognostication rule by APACHE II score and serum soluble urokinase plasminogen activator receptor. Crit Care. 2012; 16:R149.
40. Remes-Troche JM, Duarte-Rojo A, Morales G, et al. Hemoconcentration is a poor predictor of severity in acute pancreatitis. World J Gastroenterol. 2005;11:7018-7023.

41. Koutroumpakis E, Wu BU, Bakker OJ, et al. Admission hematocrit and rise in blood urea nitrogen at $24 \mathrm{~h}$ outperform other laboratory markers in predicting persistent organ failure and pancreatic necrosis in acute pancreatitis: a post hoc analysis of three large prospective databases. $A m J$ Gastroenterol. 2015;110:1707-1716

42. Puolakkainen P, Valtonen V, Paananen A, et al. C-reactive protein (CRP) and serum phospholipase A2 in the assessment of the severity of acute pancreatitis. Gut. 1987;28:764-771. 